Illinois State University

ISU ReD: Research and eData

Theses and Dissertations

6-9-2020

\title{
The Reading Eye, Ruminating Body, And Regulated Gaze: (Re)Constructing Gender In The Old English Lives Of Saints
}

Thelma Trujillo

Illinois State University, trujillo.thelma@gmail.com

Follow this and additional works at: https://ir.library.illinoisstate.edu/etd

Part of the Feminist, Gender, and Sexuality Studies Commons

\section{Recommended Citation}

Trujillo, Thelma, "The Reading Eye, Ruminating Body, And Regulated Gaze: (Re)Constructing Gender In The Old English Lives Of Saints" (2020). Theses and Dissertations. 1313.

https://ir.library.illinoisstate.edu/etd/1313

This Thesis is brought to you for free and open access by ISU ReD: Research and eData. It has been accepted for inclusion in Theses and Dissertations by an authorized administrator of ISU ReD: Research and eData. For more information, please contact ISUReD@ilstu.edu. 


\title{
THE READING EYE, RUMINATING BODY, AND REGULATED GAZE: \\ (RE)CONSTRUCTING GENDER IN THE OLD ENGLISH
}

\author{
LIVES OF SAINTS
}

\section{THELMA TRUJILLO}

60 Pages

This thesis examines the eleventh-century collection of Early English hagiography, the Lives of Saints; specifically, four female saints' lives, those of Saint Agnes, Cecilia, Eugenia and Euphrosyne. Using Judith Butler's gender performativity theory, I consider how female gender is constructed in these texts by examining gender as manifested in the late antique period when they were first written, and then, in the Early English period when they were copied and translated. This research on gender combines an array of literature, such as Latin theology, Old English laws and penitentials, Latin and Old English hagiography, and contemporary theoretical frameworks. My main argument is not only that modern frameworks of analysis can be applied to medieval literature, but also, that this literary analysis offers an opportunity to explore gender as a performative category and creates a space to interrogate the male/female binary for both contemporary readers and medieval subjects.

KEYWORDS: Medieval Studies; Old English Literature; Early English Period; Queer Theory 
THE READING EYE, RUMINATING BODY, AND REGULATED GAZE:

(RE)CONSTRUCTING GENDER IN THE OLD ENGLISH

LIVES OF SAINTS

THELMA TRUJILLO

A Thesis Submitted in Partial

Fulfillment of the Requirements

for the Degree of

MASTER OF ARTS

Department of English

ILLINOIS STATE UNIVERSITY

2020 
(C) 2020 Thelma Trujillo 
THE READING EYE, RUMINATING BODY, AND REGULATED GAZE:

(RE)CONSTRUCTING GENDER IN THE OLD ENGLISH

LIVES OF SAINTS

THELMA TRUJILLO

COMMITTEE MEMBERS:

Susan M. Kim, Chair

Tara Lyons 


\section{ACKNOWLEDGMENTS}

First, thank you to my advisor, Dr. Susan Kim, for sowing the seeds and investing so much into my growth as an individual and scholar of medieval studies. Without her, this thesis would not have been possible. I would also like to thank Dr. Tara Lyons; whose insights were invaluable for structuring and strengthening my arguments, and for always being excited about my work.

Beyond my committee, I would like to thank Dr. Kathryn Jasper for believing in me (at times, more than I did) and pointing me to various resources and opportunities. Thank you to my officemate, Heather, for her compassion, kindness, and peanut butter cookies. Thank you to Alexa (my fellow baby medievalist, friend, and ally) for being thoughtful inside and outside the

classroom, checking in on me (always more than once), and always being down to eat, chat, and drink wine. Thank you to my best friend Paola, who has been my biggest fan for the past ten years - no se que haria yo sin ti. I would also like to thank my family and my Beagle, Stewie, for always being proud of my achievements, both big and small. Finally, thank you, Craig, who was there for the 27 mental breakdowns, eight all-nighters, and stress-induced shingles outbreak it took to complete this project-I love you.

T.T. 


\section{CONTENTS}

Page

ACKNOWLEDGMENTS

i

INTRODUCTION 1

CHAPTER I: BUTLER AND PAET BODIG: CONSTRUCTING, PERFORMING, AND

(MIS)READING THE FEMALE BODY IN THE LIFE OF SAINT AGNES

CHAPTER II: GESEON DA ENG்LAS, BLOSTMAN, WUNDORGEWEORC: HERMENEUTIC VISION AND FEMALE SUBJECTIVITY IN ÆLFRIC'S LIFE OF SAINT CECILIA

CHAPTER III: 'PA CWAPP HE SMARAGDUS IC EOM GECIGED': GENDER

PERFORMANCE AND IDENTITY IN THE LIVES OF EUGENIA AND EUPHROSYNE 38

$\begin{array}{ll}\text { CONCLUSION } & 53\end{array}$

$\begin{array}{ll}\text { WORKS CITED } & 58\end{array}$ 


\section{INTRODUCTION}

Many scholars have examined Ælfric’s Lives of Saints to analyze gender and sexuality. Leslie Donovan, for example, takes a feminist approach and writes that the Lives invited women to reflect on the relationship between their spirituality and bodies and assert female autonomy. Donovan substantiates Clare Lees' claim that female saints confronted the deadliness of their bodies and sexuality and notes that: "By appropriating the same ideal of virginity that was intended to limit women's bodies and autonomy, these women saints take control of their bodies by transforming their sexuality. In so doing, they establish authority over the direction of their lives, and, especially, of their souls" (Donovan 123). On the other hand, Jocelyn WoganBrowne sees the female saints as victims of patriarchal constraint, who in their conversion from paganism to Christianity, exchange a secular patriarchy for a spiritual one. These diverse and conflicting interpretations reinforce the importance of the reader's role in experiencing texts and negotiating their meaning, but also the inescapable context of our personal experiences, research, and the politics of our time. The Lives of Saints can serve different purposes for both its medieval and contemporary audiences and can function as a discourse for both the (dis)empowerment of women. Although my answer(s) may not be, what I ask is simple: How can we bridge the gap between the female speakers of the Lives and their medieval readers, and also between medieval readers and contemporary readers?

The application of contemporary critical theories to the distant past is common, including in the field of medieval studies. Whether it is intended or not, scholars engaging in this type of application and analysis risk decontextualizing medieval texts from their social, cultural, and historical function. I respect the responsibility of situating the Lives in the historical 
and cultural context in which they were read, copied, and revised. However, I also acknowledge that the Lives, where the performance of female sanctity obscures culturally intelligible gender roles, offer an opportunity to explore gender as a performative category and create a space to interrogate the male/female binary for both contemporary readers and medieval subjects. My thesis will be grounded in a three-tier methodological approach: close textual analysis of primary source material, a historical contextualization of these primary sources and the broader sociocultural framework of the Early English period, and interpretations of the primary texts using modern paradigms of analysis like queer and feminist theory. My goal for this project is to provide a nuanced perspective on the topic of gender in the Early English period and to test the flexibility of contemporary theory. Second, I hope that engaging the Lives in conversation with the work of theorists, such as Judith Butler and Laura Mulvey, will make these texts more relevant and accessible to nonmedievalist scholars.

The key texts that will serve as the focus of my thesis are in the British Library's Digitised Manuscripts collection and are all bound to the same manuscript: Cotton Julius E. vii. This early eleventh-century manuscript contains the Old English version of the lives of Saint Agnes, Cecilia, Eugenia, and Euphrosyne.

In the first chapter, I examine the construction of female gender and sexuality as a cultural performance by using Judith Butler's gender performativity theory in conjunction with Ælfric's "Life of Saint Agnes." In Undoing Gender, Butler suggests that the body is "constituted as a social phenomenon in the public sphere" (Butler 21). This was also the case for the bodies of the female saints, which were shaped not only by male hagiographers, but also by Early English politics, culture, and religion. In the context of the Early English period, female identity depended on women's sexual activity (or lack of). For many medieval women, the traditional 
female identity was motherhood. Thus, a woman's decision to remain in the state of virginity was a denial and deviation from this culturally intelligible identity. I will argue that Agnes' performance of sainthood deviates from the traditional performance(s) of the feminine gender and transcends the masculine/feminine binary, which renders her performance even more transgressive. For example, Saint Agnes rejects marriage, sex, and motherhood, but unlike the other saints, she does not reject her sexuality or adopt "maleness" to be recognized as holy. Rather, in her use and reliance of nuptial and bridal imagery to describe her relationship with Christ, it is suggested that female sexuality and sainthood are indeed compatible and made concrete in Agnes' devotion to her celestial husband. Agnes then, transforms her relation to the constitutive norms her performances (both as a woman and saint) are dependent on, and while she is on the verge of becoming unintelligible, she also asserts agency by providing a nuanced performance within the culturally intelligible notions of identity. Using this theoretical perspective to read the Lives of Saints can provide an understanding of how gender performativity is concurrent throughout stories of the past and present.

Building from the theoretical groundwork laid out in the first chapter, the second chapter will expand the conversation to incorporate female subjectivity in my analysis of the "Life of Saint Cecilia." Unlike the "Life of Saint Agnes," where there is a desire to see the virgin martyr's naked body, the "Life of Saint Cecilia" continuously decentralizes the gaze from the saint and reallocates it to other objects: the angels, the single golden book, and the blossoms of the invisible flower crowns. The emphasis on her spirituality and intellect, then, occurs at the expense of a direct encounter and description of Cecilia's female body, and creates a hagiographic text that creates an imbalance between a lichamlïce (carnal) and gastlice (spiritual) reading. Using Emma Campell's idea of "hermeneutic vision," I examine the relationship 
between spectator, object, and the transmission of faith within the text, and argue that these visual transactions ultimately strip Cecilia of female subjectivity and relegates her to being an object, rather than subject of the text. Furthermore, to determine whether the Cecilia's role in Christian conversion was de-emphasized by Ælfric, I also compare passages from the Latin version of the life transcribed in Robert K. Upchurch's Aelfric's Lives of the Virgin Spouses (Exeter University Press, 2007). If indeed, Ælfric is averting our attention from Cecilia, I may ask, to where is our gaze being directed?

For my final chapter, I focus on the variations between two crossdressing saints: Eugenia and Euphrosyne. The latter text is bound to Ælfric's Lives of Saints; however, many scholars have argued that it was not written by him; rather, it was added to the collection by an anonymous compiler. Although both women don male attire to conceal their previous gender, they experience two different outcomes while gendered male: Eugenia becomes the object of attraction to another woman and Euphrosyne becomes the object of temptation to several monks. Furthermore, another difference between both accounts is that the anonymous author changes Euphrosyne's pronouns to respect grammatical gender, and perhaps, her male performance as the eunuch, "Smaragdus.” Euphrosyne's performance as a eunuch, which further blurs gender distinction, complicates how spiritual perfection is performed by men and women. The nuances in the lives of the crossdressing saints can reveal much about how differently Ælfric and the anonymous author constructed gender in the Early English period.

Finally, my conclusion considers how working with modern frameworks of analysis to read Early English hagiography has provided a nuanced reading and understanding of the construction of gender in this period without the divorcing it from its medieval past. 


\section{CHAPTER I: BUTLER AND PAET BODIG்: CONSTRUCTING, PERFORMING, AND (MIS)READING THE FEMALE BODY IN THE LIFE OF SAINT AGNES}

Reading Ælfric's Lives of Saints can be an alienating experience for modern readers. The paradox of the female body in these virgin martyr narratives is perplexing - it is a site of carnal sin and spiritual truth, exposed and concealed, desired and reviled, not sexed at all, yet still undeniably female. On the other hand, the female body in the Lives also functions as a site of cultural knowledge. Malcolm Godden notes

[Ælfric] clearly did see a similarity between the times of the early martyrs under persecution and the contemporary pressure, or at least, temptation to side with the Vikings, which he interpreted as abandoning faith. He also saw both Old Testament history and quasi-history embedded in the saints' legends as providing parallels and precedents for the lay nobility and clergy in the face of the troubles of their own time. (Godden 97)

The Lives, therefore, are complex and imbued with history and paradigms of belief, both late antique and medieval, and this contradictory complexity contributed to the perceived ambivalence toward the materiality of the female body in virgin martyr narratives. How are we to read such bodies, and how can the female saints help us understand the construction of gendered subjects in the past and present?

One framework that can help us negotiate and complicate the construction of gender in the Early English period is Judith Butler's gender performativity theory. In Gender Trouble, Butler builds from the work of twentieth-century philosophers and theorists (for example, 
Foucault and Monique Wittig) to center and decenter the key institutions for defining gender identities: phallogocentricism and compulsory heterosexuality. Butler asserts that gender is not an essential, innate, or biological category, but rather it is performed: "Gender is the repeated stylization of the body, a set of repeated acts within a highly rigid regulatory frame that congeal over time to produce the appearance of substance, of a natural sort of being" (Butler 22). Since gender is produced and compelled by regulatory practices, the body, then, becomes a social phenomenon shaped by politics, culture, religion, and many other factors that contribute to the production of intelligible genders. Butler defines intelligible genders as those which institute and maintain relations of coherence and continuity among sex, gender, sexual practice, and desire. In other words, the specters of discontinuity and incoherence, themselves thinkable only in relation to existing norms of continuity and coherence, are constantly prohibited and produced by the very laws that seek to establish causal or expressive lines of connection among biological sex, culturally constituted genders, and the 'expression' or 'effect' of both in the manifestation of sexual desire and practice. (Butler 17)

Gender performativity, as a framework for reading the female saints' lives, encourages scholars to examine gender performances from within the text's sociocultural context. As a social manifestation, gender performativity can reveal much about the function of the female body in Early English hagiography, as well as provide us insight into which gender performances were regulated, represented, and valued. Since the body or text remains inseparable from its medieval past, this critical analysis avoids the risk of a purely theoretically informed reading. Examining the Lives using a postmodern framework, therefore, invites an exchange of perspectives between the medieval past and modern reader. 
Using this theoretical perspective to read the Lives of Saints, I will examine Christian doctrine and Early English laws that shaped Agnes' gendered performance of sainthood in Ælfric's Old English translation. I will argue that Agnes' performance of sainthood deviates from the traditional performance(s) of the Early English feminine gender and transcends the masculine/feminine binary, which renders her performance even more transgressive. For example, Saint Agnes rejects marriage, sex, and motherhood, but unlike the other saints, she does not reject her sexuality or adopt "maleness" to be recognized as holy. Rather, in her use and reliance of nuptial imagery to describe her relationship with Christ, she is far from being male. The sexual subtext used to describe this relationship suggests that female sexuality and sainthood are indeed compatible and made concrete in Agnes' devotion to her celestial husband. Agnes then, transforms her relation to the constitutive norms her performances (as both a woman and saint) are dependent on, and while she is on the verge of becoming unintelligible, she also asserts agency by providing a nuanced performance within the culturally intelligible notions of identity.

Although both men and women can share the virtue of virginity, Early English hagiographic convention emphasized the connection between women and sexuality. For female saints, sexual condition was an official classification noted in their holy biography. Female saints were recorded as virgins, widows, or chaste wives; meanwhile, men were recorded as confessors, bishops, soldiers, and survivors of female temptation (Weinstein and Bell 87). For example, Saint Basil is recorded as a halig biscop (Clayton and Mullins 76) and Saint Sebastian as halig Godes ðegn (Clayton and Mullins 156); meanwhile, Agnes and Agatha are recorded as maeden, which is usually translated as girl or virgin. For the Lives, Ælfric maintained this convention.

In the process of selecting and translating the saints' lives from Latin to Old English, Ælfric ensured that he effectively translated late Roman culture into cotemporary Early English 
monastic culture so that the gendered performances of the saints would be coherent and thus intelligible to his primary audience: the lay aristocrats, Æthelweard and Æthelmaer. Gordon Whatley claims that Ælfric's audience are given a "narrow vision of the Christian past," and argues that the Lives "emphasize secular kings and military saints from the same social caste as Æthelweard and Æthelmaer, and noble ecclesiasts who are mainly monk-bishops and idealized versions of the leaders of the English reform party" (qtd. in Clayton and Mullins xvii). Despite the emphasis on male warrior saints, the female virgin martyrs still form a major group of the collection — specifically, there are three chaste wives Cecilia, Daria, and Basilissa, and five virgin saints, Agnes, Agatha, Lucy, Eugenia, and Æthelthryth, who is the only Early English female saint in the collection with the most historically reliable account. It can be inferred from Ælfric's selection, and omission of female saints such as the repentant prostitute Mary of Egypt and pregnant heroines like Perpetua and Felicity, that virginity was preferred as a prerequisite for female sanctity.

There are two different expressions of female virginity that Ælfric describes, those patristic in origin and those practiced by his own contemporaries. The legend of Saint Agnes first appeared in Saint Ambrose's sermon De Virginibus (c. 377) and later, in an inscription commissioned by Pope Damasus I (c. 366-384) (Donovan 47); therefore, it's important that we examine how virginity was constructed in late antiquity and how, upon its translation into the Early English period, the practice of virginity became untenable for the Early English performances of the feminine gender. Rhonda L. McDaniel, citing Jerome, Ambrose, Augustine, and Gregory the Great, outlines the concept of "metagender" in late antique doctrine. Metagender is defined as "a body that holds in itself all the positive attributes of masculinity and femininity and makes them into something greater than the sum of their gendered parts by 
melding them with the heavenly attributes of the spiritual intelligences and ultimately of Christ himself as the head of the whole body" (McDaniel 24). This concept was influenced by the importation of the monastic practice of virginity from the east to the Latin west, which was grounded at the intersection of Stoic and Neoplatonic philosophy, as well as early Gnostic Christian and Jewish interpretations of the Fall of humanity into sexed, mortal bodies (McDaniel 2). One interpretation that complicated the construction of gender in late antique Christian doctrine was the New Testament passage in Galatians 3:26-28:

omnes enim filii Dei estis per fidem in Christo Iesu quicumque enim in Christo baptizati estis Christum induitis non est Iudaeus neque Graecus non est servus neque liber non est masculus neque femina omnes enim vos unum estis in Christo Iesu [You are all truly children of God through faith in Christ Jesus. Whoever certainly has been baptized into Christ, you are clothed with Christ. There is neither Jew nor Greek, there is neither slave nor free, there is neither male or female: you are all truly one in Christ Jesus.] (McDaniel 2)

McDaniel notes that this passage suggested to its late Roman audience that gender distinctions were negated through baptism and that persons who vowed themselves to chastity would no longer be constrained to the feminine/masculine binary. Although pagan and Christian opinion considered eunuchs disdainful, monks and virgins that committed themselves to virginity (essentially, eunuchs in practice) became an idealized behavior, emphasized and prescribed by many late Roman and early medieval religious leaders who asserted chastity as the greatest sign of devotion to God (McDaniel 2). Writers, such as Jerome, Ambrose, and Augustine of Hippo, were articulate in their treatment and defense of virginity. 
Jerome addresses the topic of gender in Adversus Jovinianum (ca. 390 CE), an antimarriage treatise that exalted the practice of virginity and fasting. In this work, Jerome argues that marriage, although sanctioned by God, is an impediment that binds men and women to the temporal world, rather than to a life of single devotion to God. This sentiment is also evident in Jerome's letters to Pacatula and Eustochium, where he suggests that sexual distinctions and marriage were a result of Adam and Eve's expulsion from paradise. In his letter to Pacatula (Letter CXXVIII, ca. $413 \mathrm{CE}$ ), Jerome details how a female child consecrated to virginity should be raised and cites various biblical passages to support his ideal training for maidens. To defend his preference for virginity, Jerome cites Paul and reinforces that married couples are slaves of the flesh, while those free from wedlock serve Christ without any constraints. Jerome explains that marriage is a pellicias tunicas [the coats of skins] that Adam clothed himself with when he was expelled from the paradise of virginity: "habens uxorem et matrimonio pelle circumdatus: non quaerat virginitatis et aternae pudicitiae nuditatem, quam semel habere desivit" [having a wife and covered with the skin of matrimony: let him not seek the nakedness of virginity and of that eternal chastity, which he has forfeited once for all] (Jerome 473). Jerome asserts that carnal temptation, such as marital desire, was inevitable for Adam and Eve, and therefore, Pacatula should avoid the company of men and seek an instructor with the following qualities: "Magister egregious contemnit viros, fratres despicit et in unius mulierculae secreta erudition desudat" $[\mathrm{He}$ must be a fine teacher who despises men, scorns his brethren, and labors in secret to instruct one weak woman] (Jerome 475). This letter implies that the expulsion of Adam and Eve had the same repercussions for both genders; however, this was not the case in other letters.

In his letter to Eustochium (Letter XXII, ca. $384 \mathrm{CE}$ ), Jerome explicitly details the disadvantages of marriage for women, all of which prevent women from transcending the 
temporal world and serving Christ: "quomodo uterus intumescat, infans vagiat, cruciet paelex, domus cura sollicitet, et omnia, quae putantur bona, mors extrema praecidat" [such as pregnancy, a crying baby, the tortures of jealousy, the cares of household management, and the cutting short by death of all its fancied blessings] (Jerome 57). Expulsion from paradise, therefore, included not only marriage, but for women, motherhood as well. This interpretation of the Fall demarcates gender distinctions; however, they were not as rigid as they seemed. Indeed, Jerome suggests that gender is not tied to biological distinction when he argues that a woman can cease to be a woman if she no longer concerns herself with sexual behavior and gender roles like marriage and motherhood. Practicing chastity and devotion to God, then, allows women to transcend the masculine and feminine genders and perform a third gender or as McDaniel calls it, a metagender, that grants women a "mature spiritual discretion in all its fullness, just as any chaste man can, because she has rejected those things that differentiate her from men" (McDaniel 7).

Likewise, Ambrose, in his discussion of the soul, makes no distinction between gender. Rather, the human soul is the same for both men and women and does not possess any differences like physical bodies do. Furthermore, Ambrose expresses that corporeal life is like a garment to be removed: "She [the virgin] so strips herself of bodily acts and earthly ways, that she would not know how or even if she could put them on again. 'How could I put it on?' This is to say, with what sort of reverence, what modesty, what, finally, recollections? For by good habits the practices of former depravity are put aside" (Ambrose 30-31). In other words, the genderless soul and mind direct the gendered body and its behavior just as clothing "follows the movements of the wearer" (McDaniel 18)—a metaphor that resonates with Butler's assertion of gender as a stylization of the body. 
In Ambrose's narrative of the legend of Saint Agnes, the idea that the soul and mind transcend the gendered, temporal body is illustrated. Agnes, who exhibits strength in confronting her pagan persecutors and defending her faith, transcends the natural order of the world (that is, earthly marriage) because "quod ultra naturam est de auctore naturae est" [what is beyond nature belongs to the author of nature] (McDaniel 22). Practicing virginity and devotion to Christ, then, allowed practitioners to transcend relationships of the temporal world, and overtake a different, more spiritual role. Augustine also asserted the dichotomy between the body and the soul, and assured men and women that their spirit could remain chaste even if their body did not:

Let this, therefore, in the first place, be laid down as an unassailable position, that the virtue which makes the life good has its throne in the soul, and thence rules the members of the body, which becomes holy in virtue of the holiness of the will; and that while the will remains firm and unshaken, nothing that another person does with the body, or upon the body, is any fault of the person who suffers it, so long as he cannot escape it without sin. (Augustine 25)

It is likely that in this passage, Augustine was addressing women who were no longer virgins, since sex was believed to be an action done to a woman's body, as Karras observes, "Having had sex once did not make a man permanently impure, because men in heterosexual intercourse were not penetrated. This was a crucial distinction for Roman culture and an integral part of the double standard in sexuality that had developed" (Karras 35). The disjunction between the purity of the body and that of the soul, then, allowed more women to pursue a life of devotion to Christ. In sum, the construction of virginity in the late antique period allowed men and women to perform a third gender that pushed against the gender roles imposed by Roman society and some scriptural interpretations. In Ælfric's life of Saint Agnes, the astute defense of her virginity and 
faith remain central to his Old English translation; however, the politics and culture of the Early English period, which emphasized marriage and motherhood as a social demand for women, might have influenced the reception of this gendered performance.

Ælfric's life of Saint Agnes follows the hagiographic conventions and repeated motifs of the other virgin martyr narratives in the collection, such as an attempted seduction and torture scene, but it differs in the way that the text directs and then draws our attention away from elements of carnality and sexuality. Most importantly, Agnes' account distinctly uses nuptial imagery and the language of admiration to describe her relationship to Christ. It is possible that Ælfric's decision to translate this nuptial imagery from the Latin source was to reinforce Agnes' commitment to her religion and celestial husband in concrete terms; however, her marriage to Christ the Bridegroom, sexual status, and overall gendered performance might have been unintelligible to an Early English audience.

The preference for virginity was not dominant, or at least, not as visible in the Early English period. Indeed, the considerable Old English vocabulary for words such as "cohabitation", "marriage", "concubinage" and "polygamy" in regulatory literature suggest that there were conflicting sexual practices in Early English culture (Lees 21). Clare Lees notes that Anglo-Saxon laws attempted to regulate and punish sexual transgressions such as rape and adultery. Furthermore, since marital status (in this case, sexual condition) was combined with rank to provide women a legal identity, Early English society identified sexuality with the feminine gender. Ælfric's female saints' lives, therefore, are situated at the intersection of a new consciousness for the body generated by Christian conversion and Early English proscriptions for sexual transgressions. 
Contemporary readers tend to think of virginity as a default state that women remain in until they are sexually active, but in late antiquity, the default state was marriage. Early English, Germanic culture was family oriented, so it is reasonable to suspect that marriage was also regarded a default state or social responsibility for women in this period. For example, law codes like the laws of King Æthelberht (r. 589 - 616), later described by Bede in the Historia Ecclesiastica (ca. 731) and adapted by King Alfred (r. $871-886$ ), suggested that women were valued for their procreative function:

31. Gif friman wið fries mannes wif geligep, his wergilde abicge, 7 oðer wif his agenum scætte begete 7 ðæm oðrum æt pam gebrenge.

If a freeman lies with a free man's wife, let him buy [him/her] off [with] his/her wergild and obtain another wife [for the husband] [with] his own money and bring her to the other man at home. (Oliver 68-9)

77. Gif man mægbman nede genimep, ðam agende L scillinga, 7 eft æt pam agende sinne [82] willan ætgebicge

If a person takes a maiden by force: to the owner [of her protection] 50 shillings, and afterwards let him buy from the owner his consent [to marry her]. (Oliver 78-9)

Both laws suggest that sex with women resulted in offspring that ought to be protected by the rightful father, the woman, then, also becomes an object of his protection. On the other hand, these two laws also suggest that virgin wives ensured the purity of the husband/father's line, and thus, would be more valuable. The exchangeability of women and the cultural capital of their offspring made it difficult for women to remain in the state of virginity and devote their lives to Christ. Carol Braun Pasternack reinforces this idea and argues that "the Christian demand for individual responsibility conflicted with the familial responsibility that was characteristic of 
Germanic family life... Indeed, the responsibility of the individual person for his or her own deeds and will (or shaping of desire) is a profound point of rupture brought by Roman Christianity to Anglo-Saxon culture" (Pasternack 109). The context of Early English marriage thus informs and complicates the nuptial imagery Ælfric uses in his translation of the life of Saint Agnes.

Like most virgin martyrs, Saint Agnes rejects the temporal, social demands placed on her body - marriage, sex, and procreation — to lead a life of spiritual devotion; however, it can be argued that sexual distinction and gender roles are not negated in her performance of sainthood. Seeking her hand in marriage, the son of Symphronius offers Agnes clothes (gyrlan), gems (gimmas), and worldly adornments (woruldlice glencga). Her response is the following: Ic hæbbe oðerne lufiend, pinne ungelican on æðel-borennysse, se ðe me bead bæteran frætegunga and his geleafan hring me let to wedde and me gefrætewode mid unasmeagendlicra wurðfulness. He befeng minne swiðran and eac minne swuran mid deor-wurðum stanum and mid scinendum gimmas. . . He geglængde me mid orle of golde awefen and mid ormettum mynum me gefretewode. He æteowde me eac his ænlican hordas, ða he me gehet gif ic him gelæste. (Cotton MS Julius E VII, fol. 44v) [ I have another lover, unlike you in nobility, he who offered a better adornment and let me have the ring of his faith as pledge and has adorned me with inscrutable virtue. He has beset my right hand and also my neck with precious stones and with shining gems. . He has adorned me with a veil woven from gold and has decorated me with immense treasures. He has shown me also his beautiful treasures that he promised me if I serve him.] 
Although Agnes rejects the material treasures of her pagan suitor as reeking dung (reocendes meoxes), she suggests that she has better adornments offered to her by another lover. Readers understand that she is referring to the celestial gifts she will receive when she leaves the temporal world, but her pagan suitor does not. This explanation cited above should have sufficed; however, Agnes continues the description of her holy beloved and shifts to describing her allegiance to him as a physical one:

His ansyn is wlitigre and his lufu wynsumre; his bryd-bedd me is gearo nu iu mid dreamum... Of his muðe ic underfeng meoluc and hunig. Nu iu ic eom beclypt mid his clænum earmum; his fægera lic-hama is minum geferlæht and his blod geglende mine eah-hringas. . ponne ic hine lufige, ic beo eallunga clæne; ponne ic hine hreppe, ic beo unwemme. Đonne ic hine underfo, ic beo mæden forð and pær bærn ne ateoriað on ðam bryd-lace, pær is eacnung buton sare and singallic wæstm-bærnyss. (Cotton MS Julius E VII, fol. 44v-45r.)

[His figure is more beautiful and his love more pleasant; his bridal bed is now ready for me with delights. . From his mouth I receive milk and honey. Now I am embraced with his pure arms; his beautiful body is joined with mine and his blood has adorned my eyelids. When I love him, I will be utterly pure; When I touch him, I will be unblemished. When I receive him, I will still be a virgin and children will not fail in the marriage there, where conception is without suffering and with constant fruitfulness.] In this latter description, Agnes appears to pit Christ and her pagan suitor against each other by emphasizing the physicality and love of Christ as greater than that of the pagan suitor. Although Agnes implies that her lover is Christ, in fact, she notes that he was born from a virgin and can miraculously cure illnesses, the pagan suitor does not understand these innuendos and cannot 
help but focus on the nuptial imagery, especially, the "consummation" scene that Agnes and the text conjure.

The nuptial imagery in Agnes' discourse can be both compelling and confusing to readers. It is important to note that the language used to express admiration, respect, and friendship resembles the language present day readers use to express love and lust. Ruth Mazo Karras argues that "medieval chastity, for some people, can be called a sexual identity or orientation precisely because it was an erotic chastity. This is, it did not represent lack of desire, or a lack of opportunity to satisfy desire, but more or less a deliberate orientation of desire toward the matters of the spirit" (Karras 56). Although a fascinating argument, it is difficult to tell whether people in the Early English period considered their relationship to God and religion as a reallocation of their sexual desire - there is no textual evidence of anyone claiming religion as an alternative to sexuality. Moreover, since women were valued for their procreative function in the Early English period, it is unlikely that remaining in the temporal state of virginity was possible or ideal for medieval women. Renée R. Trilling notes that in Anglo-Saxon England "virgin bodies bear a special cultural weight. . . the premium placed on virginity in both the marriage market and in Christian theology makes this category of sexuality the primary basis for a woman's identity" (Trilling 266). For many female audience members who could not refuse to be exchanged, both because of and despite the "special cultural weight" placed on virginity, performing virginity may be considered unintelligible and an inimitable identity.

Nonetheless, Ælfric implies that Agnes’ love and desire for Christ is as strong as sexual desire. Moreover, whether the discourse is read and interpreted as sexual or not, the nuptial imagery provides an imagined corporealization of Christ and Agnes in the bridal bed-a consummation where Agnes insists that her physical body remains inviolable, like the body of 
the Virgin Mary. This complicates the intelligible gendered performances of saints because Agnes does not renounce her social function or sexual distinction; rather, in this consummation scene, she still concerns herself with the role of mother and wife, which Jerome had identified as the curse of Genesis that must be surpassed to attain "mature spiritual discretion" (McDaniel 7). Furthermore, if this scene insists that Agnes is gendered as female, then, it also reinforces heterosexual relationships (here, it is a celestial heterosexual relationship, although it can be argued that temporal, heterosexual relationships are also reinforced). Therefore, her performance of virginity, femininity, and sainthood is transgressive in the sense that she continues to practice recognizable identities, like mother and wife, but not in the temporal realm of human interactions and relationships. In other words, Agnes never ceases to be a woman.

Agnes' feminine gender is also emphasized when Symphronius threatens to have her defiled at a brothel. Before he was informed that Agnes is "cristen" and "mid dry-cræfteg afylled" (filled with sorcery), Symphronius had also interpreted Agnes' nuptial imagery as sexual and secular:

Pa puhte ðam heah-gerefan huxlic on mode paet heo operne tealde toforan his gebyrdum. Befran swapeah pearle mid mycelre ðrutunge hwaet se bryd-guma waere pe Agnes on wuldrode. (Cotton MS Julius VII, fol. 45r.)

Then it seemed shameful to the high-general in mind that she regarded another before his lineage. However, he asked exceedingly with great anger who the bridegroom was that Agnes exalted.

The desire to know the bridegroom can be juxtaposed with the desire to expose Agnes' body. After she refuses to sacrifice to the virgin goddess Vesta and renounce her Christian faith, Symphronius demands that Agnes is stripped and paraded in the streets until they arrived at the 
brothel where she would be defiled. The threat of rape substantiates Agnes' femininity because of the notion that sex was a violation and action done to a woman's body. As in many female saints' lives, torture, mutilation, and other forms of physical violence were normalized, and essentially, a prerequisite for martyrdom. Since pain is internal, it cannot be objectified; however, Shari Horner argues that making pain or potential torture visible to readers was central to these virgin martyr narratives (Horner 141). By unclothing and defiling Agnes, the pagan torturers attempted to expose and sever her Christian spirit to punish her rejection of the pagan gods. This attempt to rupture her body and faith reinforces that Agnes' female sexuality, transfigured using spiritual discourse, is essential to her performance of sainthood. Therefore, Agnes' body also functions as a site of Christian knowledge.

Like spiritual or sacred texts, the bodies of saints also contain spiritual truths. Horner notes that Ælfric's use of corporeal hermeneutics - metaphors of the body, spirit, materiality and space - allows readers to read the lives of saints in two ways: "readers may read lichamlice (carnally, in terms of the body) or gastlice, (spiritually or allegorically)" (Horner 133). A literal reading is inevitable, Ælfric acknowledges this, and asserts that it takes more than seeing or admiring a text or body to understand its spiritual signification. Symphronius, the pagan suitor, and the torturers fail to understand the "spiritual meaning" of Agnes' body and only seek to expose the naked body/text. Miraculously, God overturns the pagan attempts to expose, sexualize, and "read" Agnes' body on three occasions: first, her clothing is torn off and her hair magically grows to shield her body; second, as soon as she arrives to the brothel, God sends a bright light to blind the torturers and again, shields her body; third, he clothes her with a shiny tunic. These interventions reinforce Ælfric's idea that spiritual knowledge is deep within the surface of bodies and texts. Meaning that, Saint Agnes' physical, female body is necessary to 
produce and certify spiritual truths. To allude to Butler, I would argue that the desire to strip and expose Agnes can also be considered a desire to reinscribe her body within a culturally intelligible gender and sexuality. If the violation of her body had been successful, it would have reverted Agnes to the intelligible gender of a woman no longer in the state of virginity, likely to still be exchanged in the marriage market, and able to produce progeny or cultural capital. In other words, her body would be reinstated to the public sphere, where it can be imprinted by cultural meanings. No longer able to control her relation to the constitutive norms informing her gender, Agnes would lose the autonomy over her gendered performance; however, this too does not occur.

In Gender Trouble, Butler posits the following question: "If there is no recourse to a 'person,' a 'sex,' or a 'sexuality' that escapes the matrix of power and discursive relations that effectively produce and regulate the intelligibility of those concepts for us, what constitutes the possibility of effective inversion, subversion, or displacement within the terms of a constructed identity?" (Butler 32). Although Agnes' performance of gender and sainthood reinforces heterosexuality and culturally intelligible gender roles, Agnes' sexuality, evident in her discourse of desire for Christ, destabilizes her performance. None of the other virgin martyr narratives in Ælfric's Lives of Saints embraces female sexuality and express their devotion to their faith as a marriage between themselves and Christ. In the context of the late antique period, Agnes' perpetuation of her gender distinction complicates Jerome's idea that the curse of sexualized distinctions and marriage should be transcended in approaching the state of the virum perfectum or as McDaniel calls it, metagender. Agnes' use of nuptial imagery, then, transgresses this transformation. Furthermore, in the context of the Early English period, performing virginity and refusing to be exchanged in the marriage market would have been deemed transgressive behavior 
as well. However, since she does not actually marry Christ and produce children, she does, indeed, transcend the masculine/feminine gender by choosing virginity. In other words, while Agnes produces and naturalizes her performance of gender and sexuality, she also deconstructs and denaturalizes the late antique and Early English paradigms of femininity and sainthood. The life of Saint Agnes not only allows us to reconstruct and access the sociocultural context and the discourse(s) that attempted to establish difference between the feminine and masculine gender, but also shows how these polarities can be ruptured and resisted. Contemporary frameworks of analysis like gender performativity theory, although often paired with contemporary topics, texts, and debates, is only one tool for reading female characters in medieval texts who blur boundaries and confuse categories - a tool that can help include medieval culture and literature in the gender studies of the present. 
CHAPTER II: GESEON PA ENǴLAS, BLOSTMAN, WUNDORGEWEORC:

HERMENEUTIC VISION AND FEMALE SUBJECTIVITY IN

ÆLFRIC'S LIFE OF SAINT CECILIA

As discussed in the previous chapter, Ælfric's corporeal hermeneutics encouraged readers to push against reading the saints' bodies as simply carnal (lichamlice), suggesting that they should also be read allegorically, as containers of spiritual knowledge (gastlice). I ask, how can readers access spiritual truths if the body of the saint is obscured? The hagiographic text structures the spectator/reader's visual experience by directing and denying our sight. Unlike the life of Saint Agnes, where the pagan tormentors desire to see the saint's naked body, matters of the body are not emphasized in the life of Saint Cecilia. In fact, Cecilia's body is only mentioned twice: when she is married and martyred. Prior to her marriage ceremony with Valerian, her pagan suitor, Cecilia attempted to control Valerian's ability to see her body:

Hpæt ða cecilia hi sylfe gescrydde • / mid hæran to líce · gelome fæste / biddende mid pope $\cdot$ heo purde gescyld / pið ælce gepēmednysse oððe peres gemanan · (Cotton MS Julius E VII, fol. 213v)

[Now Cecilia clothed herself with a hair shirt next to her body, frequently fasted, praying, while weeping, that she might be shielded against every defilement or shameful action of man.]

It is unclear whether this garment was used to curb the desire of Cecilia, Valerian, or perhaps both; however, reading this passage in conjunction with Saint Jerome's discussion of Adam's pellicias tunicas (coats of skins) upon his expulsion from paradise provides an interesting contrast: "habens uxorem et matrimonio pelle circumdatus: non quaerat virginitatis et aternae 
pudicitiae nuditatem, quam semel habere desivit" [having a wife and covered with the skin of matrimony: let him not seek the nakedness of virginity and of that eternal chastity, which he has forfeited once for all] (Jerome 473). Cecilia covering herself with a hair shirt, then, can also be read as a defense of the "nakedness" of her virginity and from the "skin of matrimony." Suzannah Biernoff asserts that in medieval culture, sight was a physical act "involving the extension of one's soul to the object seen, and a reciprocal impression of that object on one's body and soul — the idea of sinning with one's eyes was more than a metaphor" (Biernoff 43). The hair garment, then, functions as protection from carnal temptation like marital desire. In this scene, denying sight of her temporal body is equivalent to directing the carnal eyes to spiritual matters.

Cecilia's body appears again when she is positioned in a bath above a burning fire as punishment for taunting Almachius and his pagan idols:

Hi cyddon pa almachie hu p mæden purh punode · / on pā hatū baðe mid halū lichaman / - furpon butan spate $\cdot$ pa sende he ænne cpellere to $/$ - hét hí beheafdian on pam hatan pætere $\cdot($ Cotton MS Julius E VII, fol. 218v)

[Then they informed Almachius how that maiden stayed in the hot bath with an unharmed body and even without sweat. Then he sent an executioner for (her) and commanded they behead (her) in the hot water.]

Both these episodes are compelling - they attempt to visually encounter Cecilia, but at the same time, readers and spectators are denied sight of the virgin martyr. Indeed, throughout the text, our gaze is directed to other objects: the angels, the single golden book, and the blossoms of the invisible flower crowns, which I will discuss further in the chapter. Despite avoiding a direct encounter with Cecilia's female body, the emphasis on her spirituality and intellect suggests that 
spiritual truths are accessible without the body of the saint, which complicates and creates an imbalance between a līchamlīce and gastlice reading. Using Emma Campbell's idea of "hermeneutic vision," I will examine the visual transactions within the text; that is, the objects required to transmit Christian faith, and how they ultimately strip Cecilia of female subjectivity, relegating her to the status of an object, rather than subject of the text. Furthermore, to determine whether Cecilia's role in Christian conversion was de-emphasized by Ælfric, I will also be citing and comparing passages from the Latin version of the life of Saint Cecilia. If indeed, Ælfric is averting our attention from Cecilia, I may ask, where is our gaze being directed?

Like intromission, hermeneutic vision blurs the boundaries between the viewing subject and the viewing object. In her essay, "Sacrificial Spectacle and Interpassive Vision in the AngloNorman Life of Saint Faith,” Emma Campbell notes:

The visual encounter as it is described in the saints' lives ... involves engagement with the ideological dimension of sacrificial spectacle that goes beyond simply 'seeing' something occur. The viewer is enclosed in the event in such a way as to suggest a form of vicarious participation in what is or has been seen, a participation that would suggest narcissistic (rather than voyeuristic) involvement (Campbell 107).

This form of enclosure insists on the viewer's negotiation of the meaning of visual experiences, which we as readers also witness. It is important to note that the "sacrificial spectacle" or martyrdom of Cecilia is only a handful of lines (approximately four sentences) and, therefore, not the most important visual encounter used to produce and enforce Christian faith. The encounters that are emphasized in the text are celestial images that require to be seen by the carnal eyes, for instance, the angel of God. 
"Sight," Suzannah Biernoff argues, "is a tool for the acquisition of knowledge, and a locus of carnal desire" (Biernoff 17). The coexistence of carnal and spiritual vision is exemplified in Cecilia and Valerian's (almost) consummation scene. In bed, Cecilia introduces Valerian to her faith and claims that Valerian will be killed by an angel of God if he defiles her. Valerian responds that unless he can see this angel, he will not believe her:

Se cniht pearð pa afyrht $\cdot \square$ c̄ to pam mædene $\cdot \cdot$ / Dó p ic geseo sylf pone engel $\cdot$ / gif pu pylt $\mathrm{b}$ ic gelyfe pinū pordum be $\mathrm{p} \overline{\mathrm{a}} \cdot / \cdot$ gif pe oper cniht cupre is ponne ic $\cdot /$ hine ic ofslea · pe samod mid him · (Cotton MS Julius E VII, fol. 214r) [The retainer then became terrified and said to the maiden 'Make that I see the angel myself, if you wish that I believe your words about it, and if that other servant is more familiar than I, I will slay him and together you with him.]

Alison Gulley argues that Valerian's Christian faith is established prior to the encounter with the angel of God, so the "angel's appearance affirms Cecilia's words, he appears not as proof" (Gulley 43). While this idea is tenable, the passage cited above suggests that Valerian's desire to know God and see the angel that protects Cecilia stems from his primary concern: to confirm that Cecilia is not betraying him for another "cniht" or secular lover. Here, Cecilia's chastity is misread as infidelity; in other words, Valerian views, reads, and understands her body in carnal, rather than spiritual terms, which makes his desire to know God carnal as well. In terms of corporeal hermeneutics, this misunderstanding reinforces the danger of reading spiritual bodies and texts at a surface-level and as passive objects.

The move between carnal and spiritual understanding, albeit a slippery one, occurs after Cecilia's instruction, Valerian's baptism, and the vision of the angel of God. In this latter visual encounter, the spectator and object, Valerian and the angel, are momentarily united and 
participate in the following transaction: the angel allows itself to be seen in exchange for Valerian's understanding of Christian faith. It is important to note that medieval visual praxes functioned and were understood differently than those of the present. There were two models of vision prevalent in the Middle Ages-extromission and intromission. Extromission considered the spectator as the source of visual perception: "[this theory of vision] viewed the eye as a lamp that sent out fiery visual rays, which literally lighted upon an object and made it visible" (Camille 22). On the other hand, intromission reversed the role of spectator and object, and asserted that the object emitted rays received by the spectator. This alternative theory, intromission, became the dominant mode of vision favored by scholars of medieval optics, artists, and spectators. Furthermore, vision was tied to knowledge. When an object was perceived, the rays traveled to the brain where the image passed through the five internal senses: sensus communis (common sense), ymaginatio vel formalis (imagination), estimativa (judgement) cogitativa (a storehouse of images), and vis memorativa (memory) (Camille 23). Intromission and the process of comprehension suggests a dynamic relationship between spectator and object, where gaining knowledge was a physical process that blurred the boundaries between active/passive and spectator/object.

Both Cecilia and the angel are objects of transmission, one through vision and the other through doctrine. Full understanding, then, comes from the embodiment of Christian faith through Cecilia, the vision of the angel of God, and the negotiation of spiritual meaning from that visual encounter. However, since the text focuses more on the description of the visual encounter with the angel, I would argue that Cecilia's embodiment of Christian faith is deemphasized in favor of asserting the representability and visibility of God through the heavenly angel. This representation, then, destabilizes Cecilia's ability to effectively teach 
Christian faith - a primarily invisible institution. In addition, the destabilization of Cecilia's role as instructor and the emphasis on visual evidence may have suggested to medieval readers negotiating this encounter that miracles, visions, and material objects were essential to understanding Christian faith. Spiritual vision, therefore, was inseparable from carnal vision.

Another compelling image is the golden book that the angel provides Valerian as further proof of God's existence. Like the vision of the angel, this scene also suggests the desire for carnal vision as proof of Christian faith:

Efne pa færlice ætforan heora gesihpū $\cdot /$ cō godes engel mid anū gyldenū geprite $\cdot / \cdot$ ualerianus feoll afyrht to eorðan $/$ pa arærde hine se engel $\cdot$ het hine rædan / pa gyldenan stafas pe him god tosende · (Cotton MS Julius E VII, fol. 214v)

[Even then, all at once before their sight, an angel of God came with one golden book (lit. writing), Valerian fell terrified to the ground, then the angel raised him up and commanded him to read the golden letters that God sent to him.]

Unlike Cecilia's threat to Valerian, that he should not defile her or else an angel would smite him, Valerian appears to be more moved by the angel, who does indeed threaten him. However, apart from intimidating Valerian, the angel also guides his comprehension of the golden book. Rather than just looking at the golden book as a passive object, the angel commands Valerian to read the inscription "Unus Deus, una fides, unum baptisma" (Ibid) and asks if it is proof enough of Christian faith: ““'Pa c̄ se engel · gelyfst pu pises · oððe licað pe elles hpæt” (Ibid). This question substantiates the idea that carnal vision drives the spiritual understanding of Valerian's Christian conversion, but also suggests that a transaction that transcends carnal vision is required between Valerian and the book. Therefore, visualizing and reading religious bodies, either that of 
a text or saint, required a blurring between the role of the spectator and object (like the angel and golden book), where both receive and produce spiritual knowledge.

The conversion of Tiberius also reinforces the importance of the vision of the angel; however, in this conversion we are also introduced to an additional object used to transmit Cecilia and Valerian's Christian faith. When Tiberius encounters the couple, he is overtaken by the smell of invisible flower crowns:

... her lilian blostm oppe rosan bræ $/$ spa pynsumlice $\square$ spa perodlice stincað $\cdot /$ Đeah pe ic hæfde me on handa pa blostman $\cdot$ / ne mihton hi spa pynsumne pyrt-bræð macian \% • ic secge to sopan p ic spa eom afylled / mid pā spetan bræða $\cdot$ spylce ic sy geednipod · (Cotton MS Julius E VII, fol. 215r).

[here it smells pleasantly and sweetly just as the blossom of a lily or fragrance of a rose. Even if I had the blossoms in my hand, they may not fashion such a delightful smell, and I say, for truth, that I am filled with the sweetest of scents, as if I have been renewed]. Valerian explains that "Purh mine bene Pe com Pæs wynsuma bræð" (Ibid) and Tiberius too can see the shining flower crowns if he converts to the Christian faith. Like the sight of the angel of God and golden book, here, the floral scent also functions as materializing the invisible to transmit Christian faith. Moreover, Valerian guides Tiberius's comprehension of the scent by claiming that the red rose indicates the blood and the white lily the body of Christ. Spiritual knowledge, again, is tied to carnal vision: If Tiberius believes Valerian and his faith, he will be able to see the flower crowns and visualize the body of Christ.

Furthermore, although the angel asserts Cecilia's role in teaching Christian doctrine, "pu gelyfdest on god purh cecilian lare" [You believed in God through the teaching of Cecilia] (Ibid)," when Tiberius asks Valerian how he came to this Christian knowledge, Valerian 
responds: "Godes engel me tæhte" [The angel of God taught me] (Cotton MS Julius E VII, fol. 215v). Here, Valerian elides Cecilia's role as the principal instructor of Christian faith, and in doing so, elides her agency in the Christian conversion process, which I will discuss later in the chapter.

Although Ælfric does not explicitly concern himself with defining gender roles in his Lives, encounters such as the one between Valerian and the angel force us to negotiate the construction of masculinity and femininity. I would argue that the angels in this text perform masculinity in a similar fashion to the pagan tyrants of the virgin martyr narratives; in this case, the angel is likened to Almachius, who also commands his servants to believe in pagan faith. Cecilia, on the other hand, does not command anyone to believe in her faith, but suggests that her faith is the only true faith and therefore, it is the best option. I assume the angels in the text are masculine, not because of their grammatical gender, but because of Ælfric's nuanced translation of the martyrdom of Tiberius and Valerian from the Latin source. In the description of Maximus' account of witnessing the angels of God retrieve the bodies of the brothers, Ælfric omits the following comparison: "et egredientes animas eorum de corporibus quasi ornatas uirgines de thalamo suo" [and their souls ascending from their bodies like richly adorned virgins from their bridal chamber] (Upchurch 205). Rhonda L. McDaniel suggests that Ælfric refused to translate this comparison either to avoid feminizing the male saints or because he feared his audience would interpret "the metaphorical gendering of the incorporeal soul too literally so that people might think that the soul is female or that they would become women at death" (McDaniel 231). Whatever the reasoning behind this omission, it seems to imply that the masculine angel(s) had more power over the indoctrination of Valerian than the feminine instructor, Cecilia. Furthermore, enclosure within this threatening visual encounter might have also encouraged a 
medieval audience to fear the angels of God, therefore, aiding the transition from the mental position of unbelief to belief of Christian faith.

The most notable distinction between the Old English translation and the Latin source is the genre itself. Robert K. Upchurch identifies the Latin legend of Saint Cecilia as a secondary, art vita. This hagiographical text is labeled secondary because it is not a testimony to the life and deeds of saints; rather, it is a "'characteristically unhistorical" account manipulated by the author for different purposes. Furthermore, the legend is an art vita because it was intended to be read in the context of a religious service:

constraints of time and a need for comprehensibility dictate that these legendary vitae, which are often abbreviations of longer texts, be concise, rhetorically spare and plot driven. Art vitae, by contrast, were read privately as devotional material or publicly when monks took their meals, and they are lengthy, elaborately constructed and rhetorically sophisticated literary creations. (Upchurch 3-4)

Ælfric's Old English translation substantially reduces the length of Saint Cecilia's Latin legend, a compositional choice he explains in the Latin preface of the Lives. Ælfric asserts that he did not translate the virgin martyr narratives verbatim, but rather, translated them "sensum ex sensu" and shortened the lengthier passions so as "ne fastidiosis ingeratur taedium" [in order that boredom may not be inflicted] (Clayton and Mullins 5). Although he maintained Cecilia's spiritual knowledge central to his translation, there are several descriptions from the Latin source that could have reinforced her keen understanding of Christian doctrine, her singular love of Christ, and her active role in the process of Christianization. By removing these descriptions, Ælfric inevitably diminishes her role in the text and directs our gaze and attention to other objects of transmission like the angel, golden book, and flower crowns. 
The Latin legend of Saint Cecilia begins with her listening and responding to the voice of Christ. This response not only propels the narrative forward, but it also reinforces her desire to learn more about him and emphasizes her intellectual activity through prayers and memorization of the Gospel and other teachings. Furthermore, in this version, Cecilia also depicts her desire for Christ using statements that may have prompted the misreading of her chastity as infidelity: Angelum Dei habeo amatorem qui nimio zelo custodit corpus meum. Hic si uel leviter senserit quod tu me pollute amore contigas, statim circa te suum furorem exagitabit, et amittes florem tue gratissime iuuentutis.

[I have an angel of God for a lover who guards my body with extraordinary jealousy. If he supposes even a little bit that you might touch me with an impure love, he will immediately kindle his fury around you, and you will lose the flower of your most charming youth.] (Upchurch 177)

Ælfric does not translate "amatorem" although he does translate Valerian's confusion of this passage. Moreover, Cecilia's conversion of Tiberius in the Latin legend exhibits her expertise in Christian theology; indeed, she lectures for around 160 lines on topics such as dead pagan idols, eternal life, the Holy Trinity, and the Resurrection, and concludes her speech with "'Hec breuiter explicaui (tibi); si quid tibi deesse consideras, quere"' [I have explained these things to you briefly; if you think of anything that you need, ask] (Upchurch 193). Here, there is no doubt that Cecilia has devoted her temporal life to the learning and teaching of Christian faith since she encourages Tiberius to ask any question. To witness and participate in this indoctrination makes her embodiment of Christian faith even more spectacular - to envision the begetting, life, death, and resurrection of Christ requires seeing Cecilia as she recites the foundations of Christianity. Cecilia's presence during these recitations is asserted multiple times; for example, "dicit ei 
Cecilia" (184), "tunc beata Cecilia erigens se stetit et cum magna constantia dixit" (ibid), and "Cecilia dixit" (186) occur multiple times throughout her exchange with Tiberius and reminds the reader that this spiritual knowledge is not disembodied, but requires a carnal counterpart. However, since Ælfric reduces her speeches to avoid boring lay readers, the other objects of Christian conversion like the angel and golden book, appear to hold the same weight as Cecilia's doctrine in the conversion of Valerian and Tiberius. The Old English version, therefore, creates an imbalance between carnal and spiritual desire, where visualizing invisible institutions is more important than comprehending the spiritual knowledge embodied by the carnal saint.

Ælfric's treatment of Cecilia’s role in Christian conversion might also provide insight into his preferences for conversionary activity in the Early English period. In his Old English translation, Ælfric links teaching with spiritual procreation when he replaces the monetary metaphor with one of spiritual childbearing. Instead of "redeem," Ælfric uses "born" in the angel's contemplation of Tiberius' conversion:

Sicut te per famulam suam Ceciliam lucratus est Dominus, ita per te quoque tuum lucrabitur fratrem, et cum eodem ad martyria palmam attinges.

[Just as the Lord has redeemed you through his servant Cecilia, so in the same way will he redeem your brother through you, and you will attain the palm of martyrdom together with him.] (Upchurch 180)

Pe bet Gode licað pin broðor Tiburtius bið gestryned purh pe to pam ecan life, swa swa pu gelyfdest on God purh Cecilian lare, and git sceolan, begen pu and pin broðor, beon gemartyrode samod 
[it pleases God the better that your brother Tiburtius be born to everlasting life through you, just as you believed in God through Cecilia's instruction; and you two, both you and your brother, shall be martyred together] (Upchurch 74).

The spiritual, rather than sexual, union between Cecilia and Valerian thus produces more spiritual offspring for the Christian Church. Furthermore, Cecilia and Valerian, in a sense, transcend their temporal, gender roles (mother and father) by abstaining from the procreation of secular offspring; however, at the same time, the spiritual childbearing metaphor allows the couple to maintain the culturally intelligible roles of husband/wife, father/mother, male/female in the context of Christian conversion.

There are diverse interpretations about Ælfric’s decision to include three different examples of chaste marriage in his Lives. One argument is that the life of Saint Cecilia served as a didactic and celebratory tool for Early English female monastic readers and listeners: "Cecilia's example as a Christian wife not only reinforced and honoured the vocations of both the traditional virgin brides of Christ and formerly married nuns, but assured them that regardless of their marital and sexual histories, they were worthy handmaidens of Christ" (Gulley 50). On the other hand, the chaste marriages can also be read as an attempt to undermine the authority of married clergyman by promoting virgin spouses as a model of sanctity. Upchurch notes that Ælfric, a supporter of the Benedictine Reform, detested the practice of clerical marriage and "found it offensive that a sexually active man would conduct mass and, at his most strident, insists that married priests divorce their wives" (Upchurch 24). The preference for virginity, then, also extends to the male clergy. Ælfric's lack of concern for the sexual status of female monastics, as well as the deemphasis of Cecilia's role as instructor, might suggest that he 
preferred male clerics as Christian converters. Indeed, in the Collectio canonum Wigorniensis (ca. 1005), Wulfstan copies the following canon in the "Gregorius dicit" section:

Mulier quamuis docta et sancta sit. uiros in conuentu docere non audeat; [Wigorniensis O (Corpus 190), 077]

However much a woman is learned and saintly. She should not dare teach men in a congregation.

Women's active participation in Christian conversion, therefore, was limited. In the Latin legend and Old English translation, Saint Cecilia participates in the conversion of Valerian, Tiberius, Maximus, and over 400 other spectators. It is likely that in the context of Wulfstan's canon and Ælfric's attitude toward married clerics, that a preaching, married, female virgin had no place in the Early English Church. This latter idea could have also influenced Ælfric's reduction of Cecilia's speeches.

Despite Ælfric's role in denying the sight of Cecilia, readers and spectators are encouraged to gaze at her during the scene of martyrdom. Renée R. Trilling notes that the body is a surface for sanctity and is "far from being something to overcome, it is a site of resistance to temporal power, and also the very medium by which the saint is able to approach and incorporate divinity" (253). Although most pagan torturers do not understand the spiritual knowledge of the saint's body, they understand that the body is a container for that knowledge, and therefore, seek to disrupt Christian faith by dismembering and torturing the body. Madeline Caviness observes that the manifestation of gynephobic brutality occurs throughout medieval and contemporary culture: "Representations of confinement, corporeal punishment, rape, and murder are indicative of the victim's progressive loss of control over her own body—first over its habitual surroundings, including clothing, next over its dermic boundaries, then over its orifices, and 
ultimately over its vital organs" (Caviness 85). Cecilia's martyrdom, compared to the other visual encounters in the text, is terse.

I would argue that despite the lack of description for the attempted dismembering of her body, this lack, in fact, asserts her female agency since Cecilia does not lose control of her body or the spiritual knowledge that it contains.

When Almachius commands Cecilia to be boiled in hot water, there is no mention of her losing her clothes, skin, or other body parts. Rather, Cecilia's body remains intact without breaking a sweat. Even when the executioner attempts to behead her, Cecilia's neck remains unbroken and she continues to preach her doctrine, without the intercession of angels, for three days. The intactness of her body reinforces that carnal vision, the ability to see that her body remains whole, is just as important as spiritual vision to produce Christian knowledge. Most importantly, it reinforces that Cecilia is more than just a vessel for Christian doctrine, she is still a feminine, wholly material body that must be seen. The speech that leads to her martyrdom can attest to this dynamic relationship between carnal vision and spiritual knowledge:

Sed ne quid deesset, etiam exterioribus oculis te cecum ostendis, cum quod omnes lapidem uidemus et saxum inutile hoc tu deum tuum esse testaris. Do, si iubes, consilium. Mitte manum tuam et tangendo disce saxum esse si uidendo non nosti.

[But so that nothing is lacking, you demonstrate that you are also blind in your external eyes, since you testify that what we all see to be stone and useless rock is your god. If you wish, I give this advice. Stretch out your hand and learn that it is stone by touching it if you do not know by seeing it. (Upchurch 214-5)] Not only does Cecilia suggest that the pagan idol does not contain any spiritual truths, at the same time, she also asserts that spiritual knowledge can be seen and touched. This argument 
verifies the importance of Cecilia's role as Christian converter. Unlike the angel, book, or flower crowns, Cecilia, who is both subject and object of our gaze, can be seen, and is therefore, the most important carnal vision for transmitting and understanding spiritual knowledge.

The combination of the medieval visual praxes that occur in the life of Saint Cecilia and modern spectatorship theory can provide a linkage between visual economies of the past and present, as well as a nuanced perspective for visualizing female saints. In "Visual Pleasure and Narrative Cinema," Laura Mulvey combines psychoanalysis, feminism, and cinema studies to introduce the following spectatorial dichotomy: the active male gaze and the passive feminine object. Building from Freud's discussion of scopophilia and sexuality, Mulvey asserts that the visual presence of women in film is an indispensable element of spectacle where women function as an "erotic object for the characters within the screen story, and as an erotic object for the spectator within the auditorium, with a shifting tension between the looks on either side of the screen" (Mulvey 838). Although "male gaze theory" emerged to criticize contemporary narrative cinema, it has also been applied to various genres across different time periods. For example, in her study, Visualizing Women in the Middle Ages, Madeline Caviness uses and expands on Mulvey's idea of the male voyeur to examine the spectatorship of the torture and martyrdom of female saints, arguing that the female saint was also a voyeur of her own destruction. Medieval visual praxes as manifested in the Lives of Saints, then, complicate Mulvey's spectatorial dichotomy since the spectator and protagonist of hagiographic texts occupies both positions - the active, desiring subject and the passive, desired object. At the same time, the combination of this theory and the medieval visual practice of intromission allows readers to see the blurred the boundaries between active/passive, spectator/object, and ultimately, the male/female gaze. Both visual practices, medieval and contemporary, show that the female 
saint, usually the subject of medieval hagiography, also exerts herself as an object, both passive and active, of Christian faith. 


\section{CHAPTER III: 'DA CWEP HE SMARAGDUS IC EOM GECIGED': GENDER PERFORMANCE AND IDENTITY IN THE LIVES OF EUGENIA AND EUPHROSYNE}

If we examine Ælfric's Lives of Saints as a guide to sainthood, it remains to consider which routes to salvation were most suitable for women. Although this collection emphasizes male warrior saints (over 12 of them), female saints still form a major part of this group, including two crossdressing saints, three chaste wives, and five virgin saints. It is important to note that the Lives of Saints has not come down to us in unmediated form, but rather, it has been combined with

four anonymous texts, distinguishable by their language and styles from Ælfric’s, despite his expressed wish that his work be kept separate from that of others. If we disregard these four saints' Lives as intruders, as we must, then we are still left with a collection that does not correspond in several respects to how Ælfric himself described it in the two prefaces that he wrote for it. (Clayton and Mullins xiii)

The four "intruders" are the lives of the Seven Sleepers, Mary of Egypt, Eustace, and Euphrosyne. Apart from Ælfric's life of Saint Eugenia, the legend of Euphrosyne is the only other narrative translated into Old English that featured crossdressing as a path to salvation.

The life of Saint Euphrosyne did not achieve the same popularity as the other saints in Ælfric's Lives; however, the anonymous legend did appear in several other collections, such as a seventh-century Greek source, multiple eighth- and early ninth-century Latin martyrologies, and Bede's Martyrology (Donovan 79). It is difficult to narrow down when this anonymous narrative was inserted into Ælfric's collection, but it is reasonable to suspect that, at some point, a 
compiler saw some resonance between the life of Saint Euphrosyne and the lives that Ælfric selected for translation — such a resonance that Ælfric's following plea in his Old English preface was ignored:

Ic bidde nu on Godes naman, gif hwa pas boc awritan wille, pæt he hi wel gerihte be pære bysne, and pær na mare betwux ne sette ponne we awendon.

[I ask now in the name of God that, should someone wish to make a copy of this book, he correct it well according to the exemplar and insert in it no more than we have translated.] (Clayton and Mullins 13)

Noting some points of similarity between the life of Saint Euphrosyne and the Lives, the compiler likely perceived the translation and addition of this holy biography as justified to disregard Ælfric's directive to keep the collection free from further modifications. It is the two crossdressing saints in the Lives, Ælfric's Eugenia and the anonymous author's Euphrosyne, that I will focus on.

Although both women don male attire to conceal their female gender, they experience two different outcomes while gendered male: Eugenia becomes the object of attraction to another woman and Euphrosyne becomes the object of temptation to several monks; Eugenia's femininity is restored, while Euphrosyne maintains her male performance as the eunuch, Smaragdus; Eugenia is martyred and Euphrosyne is not. The nuances in both accounts of the crossdressing saints can reveal much about how differently Ælfric and the anonymous author constructed gender and sexuality in the Early English period. In this chapter, I will reexamine my question posited in the first chapter, how can the female saints help us understand the construction of gendered subjects in the past and present? By comparing the two accounts, I will argue that in selecting and translating the life of Saint Eugenia to Old English, Ælfric did not 
consider crossdressing, or the blurring of gender distinctions, as a viable path to salvation. In fact, the life of Saint Eugenia draws boundaries and restrictions between men and women, especially after Eugenia is restored to her female gender half-way through her account.

In his essay “When Women Aren’t Enough,' Allen J. Frantzen affirms that Judith Butler's gender performativity theory is a valuable framework for analyzing texts. Although Butler resists considering gender performance as role-playing, Frantzen notes that "her idea of performance suggests processes important for understanding medieval texts in which gender identity are put into play" (457). Indeed, switches of gender identity, such as crossdressing, create an ideal space to interrogate the construction of gender. In the lives of Saint Eugenia and Euphrosyne, crossdressing temporarily blurs the distinction between the saints' biological gender, gender identity, and gender performance, and inevitably, reveals which aspects have been naturalized for each gendered experience. Like crossdressing, Butler asserts the following about performing drag: "In imitating gender, drag implicitly reveals the imitative structure of gender itself-as well as its contingency. Indeed, part of the pleasure, the giddiness of the performance is in the recognition of a radical contingency in the relation between sex and gender in the face of cultural configurations of causal unities that are regularly assumed to be natural and necessary" (Butler 137-8). Both gender performativity and crossdressing, then, can help readers understand how Ælfric and the anonymous author constructed gender in their Old English accounts of Eugenia and Euphrosyne.

The causes and consequences of crossdressing in medieval literature differ, even within the genre of Old English hagiography. Frantzen argues that at a surface-level, "What motivates the use of cross-dressing in medieval narratives is, in part, the traditional assumption of the superiority of the male dominated by reason, to the female, dominated by passion, and of the 
possibility of passing from the latter to the former position" (Before the Closet 73). On the other hand, in Clothes Make the Man, a study of literary and historical female transvestism [here, defined as "the desire to dress as the opposite sex" (4)], Valerie Hotchkiss notes that a male disguise had an empowering force for some female heroines; however, the interpretation of this crossdressing remains ambiguous, so she encourages readers to ask the following: "Does the empowerment of the woman in disguise empower women in general or is there a residual uneasiness with the phenomenon? Is female crossdressing a liberating and revolutionary act or a repressive and ultimately confirming validation of presupposed gender identity?" (9). These will be some questions I return to later in this chapter. Many female saints, such as Agnes and Cecilia, achieved sanctity without crossdressing as male. Indeed, the criteria for female sanctity in the Lives appears to be a combination of the following: she must be a virgin or chaste wife; she should overcome the temptation of a pagan suitor; convert people from paganism to Christianity; and succumb to the potential torture of her body. It is important, then, to examine what is gained (or lost) when crossdressing is employed as an instrument for the sanctification of Eugenia and Euphrosyne.

Both narratives indicate a reason for the switch in garments and gendered performance. At first glance, it appears that Eugenia and Euphrosyne are crossdressing to flee from their relationships in the temporal world, such as their family or future husband; however, looking closer at the details included and emphasized in each account shows how differently the texts and protagonists conceive of biological gender or anatomical sex (the gender they are assigned at birth), gender performance (the gender they choose to perform when they crossdress), and gender identity (the gender that the text or protagonist identifies as). These three terms have been adapted from Butler's discussion on the three dimensions of drag, where she notes, that drag 
presents "three contingent dimensions of significant corporeality: anatomical sex, gender identity, and gender performance" (Butler 137). I will be using these three terms in my discussion of crossdressing in the lives of Eugenia and Euphrosyne.

The life of Saint Eugenia takes place in Egypt during the reign of emperor Commodus (177-192 AD). Eugenia's father, Philip is the prefect of Alexandria and has expelled all Christians from this region. During her Latin and Greek instruction, Eugenia discovers the work of Saint Paul. Intrigued by these holy writings, she travels with her eunuch servants, Protus and Hyacinth, looking for a city where Christians still dwell. When she finds a Christian congregation, Eugenia addresses Protus and Hyacinth with the following request:

Đa nam Eugenia hi on sundor-spræce, het hi gebroða, and bæd pæt hi hyre faex forcurfon on wæp-monna wysan, and mid wædum gehiwodon swylce heo cniht wære: wolde ðam Cristennum genealecan on wærlicum hiwe pæt heo ne wurde ameldod.

[Then Eugenia took them apart in private conversation, called them her brothers, and asked them to cut her hair off in the manner of a man's and to disguise her in clothes as if she were a young man: she wanted to approach the Christians in the appearance of a man so that she would not be discovered.] (Clayton and Mullins 47-9)

The narrative sequence of the text suggests that Eugenia changes her female attire and gender performance because she wants to continue learning about Christianity without being discovered by her father. In the Latin version, however, the context of her crossdressing is complicated by the following detail:

ad diversorium hujus congregationis, in quo Deo canitur, nullam patitur venire feminarum. 
[No woman can come toward the dwelling-place of this congregation, where God is praised in song.] (Vita Sanctae Eugeniae, Cap III, A)

Here, readers are given an additional reason for Eugenia's garment and gender switch, a reason that reveals a restriction imposed on Eugenia's spiritual goal. This detail is not included in Ælfric's Old English translation and thus, the significance of crossdressing as a requirement for Eugenia's accessibility to Christianity is downplayed. In both the Old English and Latin version, the bishop, Helenus, receives a vision from God revealing Eugenia's biological gender. The next day, Helenus meets with Eugenia and admits that he knows her male attire is not indicative of her biological gender, he tells her:

Hwæt heo manne wæs and hwylcere mægpe, and pæt heo purh mægðhad mycclum gelicode pam heofonlican cyninge pe heo gecoren hæfde. And cwæð pæt heo sceolde swiðlice æhtnyssa for mægðhade ðrowian, and peah beon gescyld purh pone soðan Drihten pe gescylt his gecorenan.

[what kind of a person she was and of what family, and that by her virginity she had greatly pleased the heavenly king whom she had chosen. And he said that she would have to suffer severe persecutions for the sake of her virginity, but yet she would be protected by the true Lord who protects his chosen ones.] (my emphasis, Clayton and Mullins 4851)

Helenus emphasizes that it is not her crossdressing that has pleased God, but her virginity. It is important to note that up until this point, the preservation of Eugenia's virginity was not much of a concern for her even though it is a central theme of this text. Helenus, then, baptizes Eugenia, and allows her to secretly join the Christian dwelling-place if she remains in her male attire. Here, Helenus condones Eugenia's male gender performance, but only to the extent that it is 
meant to protect her female virginity. Although crossdressing serves a similar purpose in the life of Euphrosyne, the author's treatment of the gender switch differs.

One distinction between the crossdressing in both accounts is the way each text and protagonist contemplate the gender identity of the saint. Like the life of Eugenia, Euphrosyne's holy biography also takes place in Alexandria at an unknown date. Euphrosyne is the only daughter of Paphnuntius, a wealthy Christian man. After her mother dies, Paphnuntius teaches his daughter religious texts. Because Euphrosyne understands these texts so deeply, she becomes famous for her wisdom. Many men seek her hand in marriage, but Paphnuntius only accepts the proposal from a suitor more noble and wealthier than the others. Before she is married, however, Paphnuntius takes her to a Christian chapterhouse to be blessed by an abbot. At the chapterhouse, she stays seven days observing the religious men and their practices. Euphrosyne admires the behavior of the monks and proclaims: "Eadige sind pas weras beon pisse worulde syndon englum gelice 7 purh $\mathrm{p}$ hegaap $\mathrm{p}$ ecelíf' [Blessed are these men who are like angels in this world. Because of it, they achieve eternal life] (Cotton MS Julius E VII, fol. 208r.). Before she leaves to return home, she begs the abbot to pray that God will care for her and secure her for himself. A year later, a monk is sent to invite Paphnuntius to the abbot's ordination day celebration, but he is not home. Euphrosyne speaks to the monk and inquires about the monastic way of life. Euphrosyne decides that she wants conversion rather than marriage. The monk responds with the following plan:

'Oh, sister!' the brother said. 'Don't permit anyone to defile your body, nor should you soil your beauty with any shame. Wed yourself to Christ, who can give the heavenly kingdom in return for these transitory things. Now journey in secret to a monastery. Lay 
aside your worldly clothes also, and clothe yourself in a monk's robe, so that you will escape notice most easily. (Donovan 82-3)

Like in the life of Saint Agnes and Cecilia, this monk encourages Euphrosyne to preserve her virginity and accept Christ as her bridegroom. This passage is the only passage that explicitly addresses Euphrosyne's virginity. Euphrosyne's male gender performance, then, conceals her from her father and pagan suitor, but also functions to preserve her virginity. Moreover, after she finds another monk to cut her hair, lend her a monk's robe and bless her, Euphrosyne debates which monastery she should hide at:

Gif ic nu fare (alt. spelling for fere) to fæmnena mynstere, ponne rec[e]ð min fæder me pær 7 me pær findap ponn[e] nim[a]ð he me neadunga panon for mines brydguman pingan ac ic wille faran to wera mynstere pær nan man min ne wene. (Cotton MS Julius E VII, fol. 209v.)

[If I journey now to a monastery for women, then my father would seek me there and find me there. Then, he would seize me by force therefrom for the sake of my bridegroom, but I will travel to a monastery of men where no one would expect of me.] Although Euphrosyne was already wearing a monk's robe and thus, performing the male gender, she also switches her gender identity.

When Euphrosyne seeks admission to an all-male monastery, she changes her gender identity, and introduces herself to the abbot as a eunuch named "Smaragdus": "pa axode hwæt his nama wære pa cwæb Smaragdus ic eom geciged" [When he asked him what his name might be, he said, 'I am called Smaragdus'] (Cotton MS Julius E VII, fol. 210r.). This identification is an interesting one, especially since eunuchs were perceived as sexless. In the life of Saint Eugenia, Protus and Hyancinth also identify as eunuch, and Ælfric briefly explains the term: 
"paet synt belisnode" [that is castrated] (Clayton and Mullins 46-7). Castration in the Early English period served different purposes, especially after the Norman Conquest (1066 AD), where it became an Anglo-Norman practice for punishing political enemies or sexual offenses (Tracy 34). In the context of both the narrative of Eugenia and Euphrosyne, which take place in the late antique period (third-eighth century AD), castration was a practice used for policing female sexuality (eunuchs could be employed by men to guard 'their' women and ensure the purity of their patrilineality) or as a way for men to practice corporeal virginity. Furthermore, because Christians believed that reproduction legitimated gender and sexuality, eunuchs became a confused category. This confusion is evident in the terms used to describe castrated males, such as reliquus [remnant], quasi-hominem [almost human or half man], or one who nec convertatur in feminam nec vir relinquatur [no longer belongs to either gender] (Taylor 149). Yet, there may have been rewards for "passing" as a eunuch: Gary Taylor notes, "What does someone gain by 'passing'? The ability, the right, to pass through doors that would otherwise be closed. Literally, the eunuch is often the keeper of a door, protector or pimp, the guardian of access to a desired space, sexual or political or religious" (181-2). Euphrosyne's passing as a eunuch does just that —it gives her access to a desired, all-male religious space. Ælfric's disinclination to explain eunuchs in greater detail or include the life of Euphrosyne in his collection may suggest the following: he did not want to confuse the practice of castration for religious purposes with the practice of castration in his own time; he did not want to juxtapose two, gendered means of practicing virginity; or, he wanted to construct gender as a binary. The latter idea is tenable since in the second half of the life of Eugenia, each gender, male and female, can only convert members of their same gender to Christianity. This conversion process via gender coordination suggests that there are boundaries for the role of women in Christian conversion, and thus, 
selecting a saint who troubles but then, upholds gender categories may have been ideal for Ælfric's collection.

After Euphrosyne introduces herself as a eunuch, the text begins referring to her as Smaragdus using the Old English masculine pronouns (he/his/him/hine). Concerning this pronoun change, Leslie Donovan theorizes that "this unusual shift in pronouns suggests either that the reader is meant to see the saint as a viewer in the text would (i.e. the male monks) or that Euphrosyne's male disguise is indicative of an inward, more permanent spiritual transformation" (84). Although potentially an anachronistic reading, I would suggest that the change in pronouns respects Euphrosyne's decision to switch her gender identity and performance and could also represent a tolerance for crossdressing as a path to salvation for women. Indeed, Euphrosyne maintains her male attire and identity for 38 years, until she reveals herself to her father, Paphnuntius, on her deathbed where she dies from "natural" causes that derive from her extreme asceticism. Even after this revelation, Euphrosyne is still buried among the monastery's founding fathers.

This pronoun switch does not occur in the life of Saint Eugenia. Even if Eugenia changed her gendered performance, $Æ l$ fric does not change her gender identity — the text continues referring to her using the Old English feminine pronouns heo/hire/hie. In this sense, if we ask ourselves whether crossdressing is empowering for Eugenia, it can be argued that it is, since her gender identity is still that of a woman and her male gender performance allows her to gain privileges only men are entitled to, such as access to theology and monastic life. It is important to note that in the Latin version, after Eugenia switches garments, she also introduces herself with a male name: 
Ad haec Eugenia respondit, Cives: inquit, Romani sumus. unus ex his duobus fratribus meis Protus dicitur, alius Hyacinthus, ego vero Eugenius nuncupor. Cui beatus Helenus dixit: Recte te Eugenium vocas; viriliter enim agis, et corfortetur cor tuum pro fide Christi.

[Eugenia replied to this, 'We are Roman citizens,' she says. One of these two brothers of mine is called Protus, the other Hyacinthus, truly, I am called Eugenius. To whom the blessed Helenus said: Rightly, you are called Eugenius; that is to say, you act manfully and may strengthen your heart much for faith in Christ] (Vita Sanctae Eugeniae, Cap. VII, B)

However, since Eugenia's biological gender is revealed in a vision prior to meeting her, Helenus and the Latin author do not switch her gender pronouns or identity. It is unclear why Ælfric would omit this detail, but I would suggest that it helped to emphasize that Eugenia's biological gender and identity are still female.

The consequences for each crossdressing saint are similar even if the outcome of their gender switch is not. Both Eugenia and Euphrosyne, despite their performance of male gender and spirituality, are not liberated from the threat of sexuality. Valerie Hotchkiss notes, "Perhaps in an effort to prove that femaleness and its attendant sinfulness cannot remain hidden, the authors consistently introduce sexuality into the lives of these female monks. The sexual vulnerability of the disguised woman is a recurrent theme in the lives, and it is of particular significance in the legends of the female monks" (25). Three years after her gender switch, Eugenia becomes the abbot of the Christian dwelling-place and acquires divine healing powers. She heals a rich woman named Melantia who becomes attracted to her. After Eugenia rejects the 
treasures Melantia offers as a reward for curing her, Melantia pretends to be sick and attempts to sexually assault Eugenia:

'Nu ic min mod awend mycclum to ðe, pæt pu hlaford beo pære æhta and min. Ic wene pæt hit ne sy unrihtwisnysse ætforan Gode peah ðe pu wifes bruce and blysse on life' ... beclypte seo myltestre pæt clæne mæden and wolde hi gebygan to bismorlicum hæmede. [Now my heart is directed very much to you, that you should be the lord of my possessions and of me. I believe that it is not the wickedness in the eyes of God if you have sex with a woman and have pleasure in this life ... that prostitute embraced the pure virgin and wished to persuade her to engage in shameful fornication]. (Clayton and Mullins 54-5).

Concerning this scene of same-sex desire, Frantzen notes, "female sexual aggression is mocked in Eugenia's life, in which the saint's beauty as an abbot incites another woman's lust. This test of the saint's virtue is presumably safe and perhaps, no test at all, since the idea of a woman's sexual attraction is to another not seriously entertained" ("When Women Aren't Enough", 466). Although the possibility of same-sex desire in the Early English period is considered, especially in the Old English penitentials where same-sex acts are punished [ex: "Sodomites shall do penance for seven years, and the effeminate man as an adulteress" and "If a woman practices vice with a woman, she shall do penance for three years" (McNeill and Gamer 185)], here, in this text, it is not since Eugenia is preserving her chastity for salvation. Feeling spurned, Melantia goes to the prefect of Alexandria (Eugenia's father) and accuses Eugenia of an attempted rape. To prove that she did not do this, Eugenia proclaims the following:

Hwæt ða Eugenia, seo æpele fæmne, cwæð pæt heo wolde hi sylfe bediglian and Criste anum hyre clænnysse healdan on mægðhade wuniende, mannum uncuð, and forðy 
underfænge æt fruman pa gyrlan wærlices hades and wurde geefsod. After pysum wordum heo totær hyre gewædu and ætæwde hyre breost pam breman Phillipe. . . [Well then, Eugenia, the noble virgin, said that she had wanted to hide herself and preserve her purity for Christ alone, living in virginity, unknown to people, and for that reason she had at first assumed the dress of the male sex and had had her hair cut. After these words she tore apart her clothes and revealed her breast to the illustrious Phillip...] (Clayton and Mullins 58-9)

Although narrative sequence suggests that Eugenia switches her gender to learn more about Christian theology, here she argues that her gender switch was to preserve her virginity for Christ. Once she exposes her biological gender, Eugenia's female gender performance and identity are restored. Because of this restoration, I would argue that crossdressing does not have the same significance as it does in the life of Euphrosyne. Indeed, Eugenia overcomes the threat to her virginity not because of her male disguise, but because she succeeds in preserving her virginity and rebuking Melantia for her sexuality.

Similarly, Euphrosyne's male disguise also materializes same-sex desire; however, this desire comes from within the monastery. When the abbot introduces Euphrosyne/Smaragdus to the other monks, she/he incites their lust:

Because Smaragdus was so beautiful in appearance, the accursed spirit would send continual thoughts into their minds. Whenever the brothers came to the church they became sorely tempted by Smaragdus' fairness. (Donovan 85 )

To suppress their sexual desire, the abbot requests that Euphrosyne pray and fast in an insolated cell, away from the other monks. Frantzen asserts that the narrative curbs the risk of homosexuality because Euphrosyne's biological gender is actually female ("When Women 
Aren't Enough, 466); however, I would argue that since the physiognomy of some eunuchs and women was similar, it is possible that the narrative is suggesting not only that monks are not devoid of sexuality, but that both men and women can pass as a eunuch. Eunuchs were socially identified by the following characteristics: facial pallor or beardlessness, cultural marks like earrings or uniforms, and if castration occurred while the male was still a boy, the Adam's apple would not develop and the "rib cage disproportionally expand[ed], and in combination these two physical features produce[d] a unique vocal register" (Taylor 38). Euphrosyne, then, can certainly pass as a male eunuch despite her biological gender. It can be argued that $Æ l$ fric might have perceived this blurred gender performance as problematic and unintelligible to his Early English audience. In fact, Catherine Cubitt suggests

Ælfric's homiletic writings do not, however, operate on a simple representational level; his saints are not straightforward role models for men and women. For example, Ælfric includes a sermon on the transvestite saint, Eugenia, in which her activities are related with nothing other than approval. It is most unlikely that he intended that this saint should inspire her Anglo-Saxon sisters to imitation since he explicitly condemned the practice of cross-dressing in his pastoral letters. (15)

It makes sense, then, why Ælfric preferred the life of Saint Eugenia where crossdressing temporarily protected the saint's chastity. On the other hand, the crossdressing in the life of Euphrosyne is not temporary, rather, her male gender performance is maintained for 38 years. As discussed in my first chapter, virginity and sainthood in the Early English period differed in thought and practice since women had social demands, such as marriage and motherhood, that did not make practicing virginity ideal. Excluding the life of Saint Euphrosyne from Ælfric's 
collection, however, suggests that neither crossdressing or passing as a eunuch is ideal neither in thought nor practice.

Comparing the narratives of the two crossdressing saints reveals a disjunction in the Early English construction of gender. The anonymous text insists that Euphrosyne, despite her biological gender, can successfully perform and maintain a male gender identity; meanwhile, Ælfric suggests that although Eugenia's virginity is best protected when she switches her gender identity to male, she can only achieve sanctity after her female biological gender is restored and when she is martyred as a woman. The compiler who disregarded Ælfric's directive to avoid modifying the collection must have perceived the life of Euphrosyne as offering an alternative outcome for women — one that does not lead to martyrdom and yet, still helps the female saint achieve sanctification - an outcome that might have prompted women to consider what they might be able to gain by switching their gender performance. In a sense, the life of Saint Euphrosyne, appears to make holy life more accessible for women.

Now I ask the same question Hotchkiss does: "Is female crossdressing a liberating and revolutionary act or a repressive and ultimately confirming validation of presupposed gender identity?" (9). I think it is both. To an Early English audience, where women had different social demands, crossdressing might appear to be a liberating and transgressive act; however, for most, maintaining virginity or switching gender was not possible. For modern readers, reading medieval crossdressing narratives can also help us understand the distinctions between biological gender, gender performance, and gender identity - the categories Euphrosyne triumphantly troubles. 


\section{CONCLUSION}

This project started with confusion. After my initial encounter with Ælfric’s Lives of

Saints, I was not sure what to make of the female protagonists: Are they heroines pushing against the life that their suitors or fathers decided for them or were they just choosing another life decided for them by religious men? Why do they seek sanctification through such violence? And finally, the question I posit in my introduction, how can we bridge the gap between the female speakers of the Lives and their medieval readers, and between medieval readers and contemporary readers? It is this latter question that encouraged me to find a way to read these texts from my own sociocultural context, but also without alienating the context of the Early English period.

To understand the female saints and their embodiment of Christian spirituality, it is also important to understand how gender functioned in the Early English period. Although Judith Butler's gender performativity theory was developed in response to the feminist debates of the late eighties and nineties (i.e. the question of "what makes a woman?" and the rejection of a mutually exclusive gender binary), this framework can also be synthesized to the following premise: gender is a socially and culturally produced phenomenon. Furthermore, because this framework asserts that gender is constructed by sociocultural conditions, it allowed me to explore gender performance and the role of female sanctity without divorcing the Lives from its medieval context. What I discovered from this application and analysis is that the female saints I examine_-Agnes, Cecilia, Eugenia and Euphrosyne — can both produce and resist the gender essentialism that Latin theology and Old English laws and penitentials attempted to establish. It is the combination of this historical background and a contemporary theoretical framework that 
helps modern readers understand how these female saints construct and problematize gender in their time and ours.

In my first chapter, I examine the practice of virginity from the late antique and Early English period in the "Life of Saint Agnes." One important point of distinction between practicing virginity in the late antique period, the time that these texts were written in their original Latin, and the Early English period, the time when they were copied and translated to Old English, is that although corporeal virginity was encouraged in thought, it was difficult to practice. For women in the late antique period, practicing virginity allowed them to transcend the temporal world and the gender distinctions imposed by Adam and Eve's expulsion from paradise (for women, marriage and motherhood) and allowed them to perform a "third gender" encouraged by the Latin Doctors. However, in the Early English period, which was influenced by family-oriented Germanic culture, marriage and motherhood were social demands that often could not be circumvented. In fact, in his Old English preface, Ælfric does not encourage his readers to exemplify the saints in his collection or in previously translated collections, but suggests simply to honor them to strengthen their faith, "and lif pe Angelcynn mid freols-dagum wurpað" [and lives that the English people honor with feast days] (Clayton and Mullins 9). Using gender performativity theory, readers can the complexity of Agnes' performance of female sanctity and gender, as well as the way it manifests both cultures - that of late Rome and the early Christian, Germanic England. Agnes is a virgin who transcends the temporal world and its demands for women, yet, she also succumbs to those same demands in the celestial realm: she is the bride of Christ and a mother to future Christian coverts. This latter idea is suggested by the following "Đonne ic hine underfo, ic beo mæden forð and pær bærn ne ateoriað on 
ðam bryd-lace, pær is eacnung buton sare and singallic wæstm-bærnyss" [When I receive him, I will still be a virgin and children will not fail in the marriage there, where conception is without suffering and with constant fruitfulness] (Cotton MS Julius E VII, fol. 44v-45r.) So, while she produces and naturalizes the intelligible performance of the female gender (marriage and motherhood) in the Early English period, she also resists it by denying the performance of these roles in the temporal world.

In my second chapter, I continue to examine the embodiment of Christian spirituality in the "Life of Saint Cecilia." Specifically, I argue that Ælfric's Old English translation reduces the role of the female theologian, Cecilia, by obscuring our sight of the female body (the container of spiritual truth) and redirecting our focus to other objects of transmission for Christian faith. I suggest that the omission of certain details from the Latin version of the holy biography, as well as Ælfric's attitudes about male monastics, may have implied that teaching and preaching religious faith was not ideal for women. Most importantly, what can be gained from this reading and analysis is that medieval visual praxes often required seeing objects to attain knowledge. Meaning that, it is essential to see Cecilia to behold the spiritual knowledge that she contains and transmits. In this sense, Cecilia is not a passive object, but also an active subject. Because the gaze and acquisition of knowledge functioned differently in the medieval period, I assert that a contemporary framework of analysis, like Laura Mulvey's male gaze theory would be amiss —at least without examining medieval optics. If readers were to make connections between medieval visual praxis and the Mulvian gaze; however, we would find that Cecilia blurs the distinctions between active/passive, object/subject, and ultimately, male/female gaze. The combination of historicism and contemporary theory, then, can still produce a complex reading. 
My third chapter focuses on the variations between two crossdressing saints in the Lives: The "Life of Eugenia" translated by Ælfric and the "Life of Euphrosyne," which was added by an anonymous compiler to the collection. In this chapter, I also use Butler's gender performativity theory, and adapt her discussion on drag where she notes that drag performances blur the distinctions between biological gender, gender identity, and gender performance. Adapting these terms, I analyze how the protagonists and text itself approaches the gender switch. I focus on several distinctions between both holy accounts, but the ones I find most compelling are that Eugenia is restored to her female gender, while Euphrosyne maintains her eunuch identity until her death. I suggest that Ælfric, although he did not consider his collection as exemplars for Early English women, may have preferred "The Life of Saint Eugenia" because crossdressing was a temporary instrument for preserving her virginity. On the other hand, Euphrosyne changes her pronouns, her name, and maintains her male gender performance for over 38 years. I argue that this account condones crossdressing and may give women the idea that they can circumvent their female gender and the social demands that come with it by changing their clothes. Gender performativity theory in this reading, then, makes the act of crossdressing more dimensional than just donning male garments. It also asks us to consider the same question Butler considers in her time: what makes a woman?

My analysis of Ælfric's Lives creates a space to critically consider how medieval texts and contemporary theoretical frameworks can be reconciled to produce a complex reading informed by both the past and present. It is important to note that although Butler's gender performativity theory lends itself well to medieval literature, other frameworks, for example, Laura Mulvey's male gaze theory, might not. This is not to say that the Mulvian gaze is inapplicable to other time periods, but that sometimes, more research needs to be done to fix. Nonetheless, a balance between 
historicism and presentism allows us to learn about the sociocultural context of the Lives, while also providing us a way to understand and acknowledge the similarities (as well as differences) of constructing gender in the medieval past and present. I hope that this study has shown how medieval literature can speak to us and what can be gained from engaging these texts in conversation with our own time. 


\section{WORKS CITED}

Ælfric of Eynsham. Lives of the Saints. ca. first third of $11^{\text {th }}$ century, British Library, London. Cotton MS Julius E VII, fol. 213v.-219r.

- Old English Lives of Saints, vol 1. ed. and trans. by Mary Clayton and Juliet Mullins. Harvard University Press, 2019.

Ambrose, Bishop of Milan. On Virginity. trans. Daniel Callam. Peregrina Publishing Co., 1991.

Aurelius Augustine. The City of God, vol. I. edited by Marcus Dodds. Edinburgh: T. \& T. Clark, 38, George Street. Pub. for Project Gutenberg. http://www.gutenberg.org/files/45304/45304-h/45304-h.htm\#Page_521

Anonymous. Vita Sanctae Eugeniae Virginis Ac Martyris [0500-0600]. Documenta Catholica Omnia Database, http://www.documentacatholicaomnia.eu/04z/z_05000600_Auctor_Incertus_Vita_Sanctae_Eugeniae_Virginis_Ac_Martyris_MLT.pdf.htm 1

Bell, Rudolph M. and Weinstein, Donald. "Chastity." Saints and Society. The University of Chicago Press, 1982. pp. 73-99.

Biernoff, Suzannah. Sight and Embodiment in the Middles Ages. Palgrave Macmillan, 2002. Butler, Judith. Gender Trouble. Routledge, 1990.

Campbell, Emma. "Sacrificial Spectacle and Interpassive Vision in the Anglo-Norman Life of Saint Faith." Troubled Vision: Gender, Sexuality, and Sight in Medieval Text and Image, edited by Emma Campbell and Robert Mills. Palgrave Macmillan, 2004. pp. 97-115.

Caviness, Madeline H. Visualizing Women in the Middle Ages: Sight, Spectacle, and Scopic Economy. University of Pennsylvania Press, 2001. 
Cubitt, Catherine 'Virginity and Misogyny in Tenth- and Eleventh-Century England.' Gender \& History, Vol.12 No.1 April 2000, pp. 1-32.

Donovan, Leslie A. Women Saints' Lives in Old English Prose. D. S. Brewer, 1999.

Frantzen, Allen J. Before the Closet: Same-Sex Love from Beowulf to Angels in America. The University of Chicago Press, 1998.

- “When Women Aren't Enough.” Speculum, vol. 68, no. 2, 1993, pp. 445-471. JSTOR, www.jstor.org/stable/2864560

Godden, Malcolm R. “Ælfric's Saints' Lives and the Problem of Miracles”, Leeds Studies in English, vol. 16 (January 1985), 83-100.

Gulley, Allison. The Displacement of the Body in Alfric's Virgin Martyr Lives. Ashgate, 2014.

- "'Seo fæmne pa lærde swa lange pone cniht oðpæt he ge-lyfde on pone lifigendan god': The Christian Wife as Converter and Ælfric's Anglo-Saxon Audience.” Parergon, Volume 19, Number 2, July 2002, pp. 39-51.

Horner, Shari. "Bodies and Borders: The Hermeneutics of Enclosure in Ælfric's Lives of Female Saints." The Discourse of Enclosure: Representing Women in Old English Literature. State University of New York Press, 2001. pp. 131- 172.

Hotchkiss, Valerie. Clothes Make the Man: Female Cross Dressing in Medieval Europe. Garland Publishing, 1996.

Jerome, St. Select Letters of St. Jerome. trans. F. A. Wright. Harvard University Press, 1954.

Karras, Ruth Mazo. Sexuality in Medieval Europe: Doing unto Others. Routledge, 2005.

Lees, Clare A. "Engendering Religious Desire: Sex, Knowledge, and Christian Identity in AngloSaxon England." Journal of Medieval and Early Modern Studies, vol. 27 no. 1, 1997, pp. 17-46. Project MUSE, muse.jhu.edu/article/16448. 
McDaniel, Rhonda L. The Third Gender and Alfric's Lives of Saints. Medieval Institute Press, 2018.

Medieval Handbooks of Penance: A translation of the principal libri poenitentiales and selctions from related documents, ed. and trans. by John T. McNeill and Helena M. Gamer. Columbia University Press, 1990.

Mulvey, Laura. "Visual Pleasure and Narrative Cinema." Film Theory and Criticism: Introductory Readings. Eds. Leo Braudy and Marshall Cohen. New York: Oxford University Press, 1999: 833-44.

Oliver, Lisi. The Beginnings of English Law. University of Toronto Press, 2002.

Pasternack, Carol Braun. "Negotiating Gender in Anglo-Saxon England.” Gender and Difference in the Middle Ages, ed. by Sharon Farmer and Carol Braun Pasternack. University of Minnesota Press, 2003.

Taylor, Gary. An Abbreviated History of Western Manhood. Routledge, 2002.

Tracy, Larissa, editor. Castration and Culture in the Middle Ages. Boydell \& Brewer, 2013. JSTOR, www.jstor.org/stable/10.7722/j.ctt2tt1pr

Trilling, Renee R. “Heavenly Bodies: Paradoxes of Female Martyrdom in Ælfric’s Lives of Saints." Writing Women Saints in Anglo-Saxon England, ed. Paul E. Szarmach. University of Toronto Press, 2013.

Upchurch, Robert K. Alfric's Lives of the Virgin Spouses. Exeter University Press, 2007. 